\title{
Analyses of the Way to Fostering the Integrity Awareness of College Students to Highlight the Political Elements
}

\author{
Xi Chen \\ Chongqing Technology and Business University \\ Department of Accounting \\ Chongqing, China
}

\begin{abstract}
To foster integrity awareness is an important part of the ideology and political work in colleges and universities. This requires colleges and universities to carry out this work under the leadership of the Communist Party of China, using practical ideology and political theory courses, making good use of Student Party and League branches, and focusing on socialist core values. Let the theory, module and self-cultivation of integrity awareness permeate with political elements, which make college students become the builders and successors of socialism under the guidance of correct political direction.
\end{abstract}

Keywords - ideological politics; cultivation of integrity; political elements; the spirit of the 19th National Congress of the Communist Party of China

\section{INTRODUCTION}

Youth is an important force in promoting historical development and social progress, which is the cause of socialism with Chinese characteristics builders and successors. As a university gathering of out-standing youth which shoulders the important political mission to train people who are needed in social development, it's necessary to highlight its distinctive political ideological and political work. Fostering college students' awareness of integrity is an important component of the ideological and political work of colleges and universities[1], whose most essential elements are to show the political. Nevertheless, the college students lack the level of political elements in the incorruption consciousness educational theory level, the mode of education level and the self-cultivation level that make them cannot acclimatize themselves to the new era, new circumstance and new demands. It is urgent to start with the position of the leadership of the Party's work in universities, ideological and political courses, Party branch and League branch, finding the realization way to training the college students' awareness which indicates the distinctly political elements.

Chongqing's social scientific program- Fostering the Integrity Awareness of College Students under the spirit of the 19th national congress of the CPC(item number-2018PY35).
II. The Proposition ANALysis of CollegE IDEOLOGICAL AND POLITICAL WORK TO INDICATE THE POLITICAL ELEMENTS

A. The spirit of the 19th national congress of the CPC gives an explicit direction of college ideological and political work to indicate the political elements

College ideological and political work is a specific embodiment that the party leads college work. General secretary Xi Jinping stressed that: "Our university which is led by the party is the socialist universities with Chinese characteristics" "To foster the successors and builders of institutions of socialism which are all-round development of morality, intelligence, physique and art, we have to adhere to the right political orientation" [2]. As a university rooted in the land of China, we must strengthen the lead and guide of the party Construction work, stick to the Party's educational policy, put the being strict in Party discipline into practice; we must implement the fundamental task of strengthening moral education and foster people, strengthen the Party's construction in colleges especially the ideological construction, intensity arming with Marxist theory, foster people with scientific theory, guide people with right ideal; we must adhere to the socialistic schooling direction, associate higher education development with realistic goals and future direction in our country without consciousness, serve the people consciously, serve the CPC and help to govern the country, serve to consolidate and develop the socialist system with Chinese characteristics, serve for the reform and opening-up and socialist modernization. All of these cannot do without the leadership of the Party and ideological and political work.

B. The spirit of the national conference on ideological and political work in colleges and universities raises clear requirements on ideological and political work in universities to highlight political elements

General Secretary $\mathrm{Xi}$ Jinping stressed in the National Conference on Ideological and Political Work in Colleges and Universities that, we should take strengthening moral education and foster people as the central link, put ideological and political work through the whole process of education and teaching. Ideological and political work in university 
determines what kind of people they foster, how to train people and train them for whom which is the fundamental question, we have to intensity arming with Marxist Theory, improve the affinity and effectiveness of Ideological and political work in colleges. Consolidate the Dominance of Marxism in college Ideology; we must put the right political direction, value orientation and educational guidance through the whole process of running a school to ensure teachers and students in university to gather around the Party, become strong believers in Marxism, active communicators and role models; we must insist the unity of the Party and the people, unify the Party's proposition and the voice of the masses in universities, elevate the interests and demands of the masses in universities to the height of political principles and positions to reflects the Party's proposition. We should put the ideological and political work in universities into an ideological work responsibility system, improve the leadership and speaking the right of ideological work in universities[3]. Grasp the critical period of the formation and determination of youth's value. Guide youth to step the first right step to make sure that the universities are always the strong position that adheres to the leadership of the Party.

\section{The construction of the party conduct and of and of an honest and clean government and the "Three No" mechanism of anti-corruption work put forward the specific requirements for the Ideological and political work in universities to highlight political elements}

The report of the 19th National Congress of the Communist Party of China pointed that: "to intensify the fear of corruption, lock up the cages that cannot corrupt, improve the selfconsciousness that does not want to corrupt. Our political environment will, through tireless efforts, like the seas fell calm and rivers running clear, be clean and free of corruption” . Currently, the situation in the fight against corruption remains grim and complex, some universities weaken the Party's leadership and do not take their responsibility of being strict in Party discipline in an all-round way. Some college teachers have vague or even wrong understanding of the important principle and major issue of principle problems. Break the law and discipline in key areas occur from time to time. Some college student organizations are proved that to corrupt and hide expenses, do black casework in cadre election and some other corruption, of which roots lie in the lack of awareness of integrity[4]. Universities should carry out the new requirements of being strict in Party discipline in the new era deeply, prevent corruption at the source, make efforts to teach college students do not want to corrupt in the inner consciousness, train them with the incorruption consciousness constantly. Let the ideological and political work in college take true liability to guide and lead the college students.
III. To Foster CurRent COLLEGE STUdENTS WITH INCORRUPTION CONSCIOUSNESS TO HIGHLIGHT THE POLITICAL ELEMENTS

\section{A. The level of educational theory on incorruption consciousness of college students is lack of political elements}

The construction in a new era always stresses that: "taking the political construction of the Party as the leader" . It is a major innovation in the construction of Marxist party theory and the vital content in the Xi Jinping's New Thought of Socialism with Chinese Characteristics in the new era that raise to put the political construction of the Party in the first place as the fundamental construction of leading the overall construction of the Party. Our universities are leaded by the Party, we must adhere to the leadership of the Party, make talking about politics as a consistent requirement. However, some universities are secretive about talking politics, they claim that the university is the academic ivory tower without politics, which seriously stop the pace of cultivating college students' awareness of integrity to highlight the political elements. Although the Ministry of Educational issued Opinions on the Comprehensive Education of Integrity in Primary and Secondary Schools, every college has been actively studying the problems of building a clean and honest government and anti-corruption. But the research institutions of the universities usually pay more attention to the theoretical research on the anti-corruption and the construction of the clean and honest government in the whole society, and not focus on the theoretical research of their own construction of clean[5]. Particularly, the study of the characteristics and laws of the construction of clean culture and the clean education of college students is not deep enough. As a result, theoretical research in the fields of political culture construction, university clean culture and college students' clean education in universities cannot fully meet the requirements of the Party's construction in the new era.

\section{B. The level of education model which cultivate college students with an awareness of integrity is the lack of political elements}

The report of the 19th National Congress of the Communist Party of China clearly states that socialism with Chinese characteristics has entered a new era, which is a new historical orientation for China's development. In the new historical context, the main contradictions in our society have also undergone historic changes, which have been transformed into the contradiction between the people's growing need for a better life and the unbalanced and inadequate development. This “unbalanced and inadequate development” necessarily includes the imbalance of development such as the education industry. In order to solve the problem of imbalance and insufficiency of education, universities must deeply understand the scientific connotation of the new historical orientation, understand the new changes and requirements in college students' education which are brought by the new historical orientation, seriously implement the goal of strengthening moral education and cultivate people, cultivate socialist builders and successors with all-round development of morality, 
intelligence physique and art, take morality as the first requirement which embody the great importance that attach to the moral education for college students and the ideological and political work. Nevertheless, the cultivation of college students' awareness of integrity is still in the inherent mode incurrent universities, they still hope to give college students a sense of integrity through several lectures about the construction of honest government and anti-corruption which has completely failed to meet the higher educational requirements in the new historical orientation, combine it with the state's goal of cultivating college students and embody the state's level of the political intention.

\section{The level of education model which foster college students with an awareness of integrity are lack of political elements}

The theme of the report of the 19th National Congress of the Communist Party of China was "remaining true to our original aspiration and keep our mission firmly in mind...making unremitting efforts to realize the Chinese Dream of the great nation rejuvenation". Youth is the hope of the state and the nation. We must firmly establish the common ideal of socialism with Chinese characteristics to make unremitting efforts to realize the Chinese Dream of the great nation rejuvenation. On May 3, 2017, General Secretary Xi Jinping stressed during a visit to china's University of Political Science and Law, that he hoped "everyone can be persistent, practice the ideal pursuit of following the Party with a whole lifetime. The Communist Youth League is the assistant and the reserve army of the Party, we should always be advanced, the broad mass of youth members of the League firmly follows the Party, which we called is the original desire and aspiration. Remembering this original desire and aspiration is the political choice of the broad mass of young people, which is also the direction of life for the youth in our country" . Remain true to our original aspiration, it requires college students to have firm political choices, carry forward the ethos and the spirit of times, strengthen the Patriotism, Collectivism and Socialist Education, set up a correct conception of history, nation, state and culture in order to devote our wisdom and power to realize Chinese dream. However, college students are still short of the awareness of self-integrity when they concentrate on reading books and seeking knowledge. Many college students think that integrity has nothing to do with themselves, it is only a matter for the civil service. Many student cadres think that divide the supplies into the activities without permission and dinner after activities and ask the school to the account are a normal phenomenon. Seeking personal connection to support themselves in the student cadre campaign, invite them to dinner after the success of the election are even more commonly seen. Only a few college students think about the deep-seat problem behind this. They are still in the perspective of the purely personal development to think about these problems, do not think themselves as the hope for the state and nation and understand their own value and the youth's value from a political point of view.
IV. Analyses of the Way to Cultivating the INCORRUPTION CONSCIOUSNESS OF COLLEGE STUDENTS TO Highlight THE POLITICAL ELEMENTS

A. Grasp firmly the leadership of the party over the work of universities to guarantee that the cultivation of the college students' awareness of integrity is along the right path

Ideological and political work in universities is the specific embodiment of the leadership of the Party and also an essential grasper to carry out the construction of the Party in universities. The Party Committee of the University should earnestly fulfill the leading responsibility of the socialist university with Chinese characteristics and adhere to the guiding position of Marxism. Firmly grasp the correct political direction of running a school and perform the function of good clearance orientation to bring the cultivation of college students' awareness of integrity into the responsibility system of the work of Party building and ideology. Achieve the same deployment, same implementation and promote integration. We should effectively strengthen organizational leadership and form a unified leadership of the Party Committee and a working pattern in which all sectors work together to manage. We should lay a cage in the system, strengthen the execution of the work, and earnestly implement the school party committee, the general branch of the party, the secretary of all party branches, the first responsibility of the Party committee and its members to refine the work tasks, assign responsibilities to the people. Form the responsibility system and resultant force of the construction of the Party's work style and clean government. A college leader should take charge of the cultivation of college students' incorruptibility consciousness, and study the work at least once a year, so as to solve the major problems and outstanding problems in the work. Sufficient time and energy should be devoted to strengthening research and research and taking the lead in enforcing regulations. University leaders and teachers should take the lead in setting a good example, play the role of the "key minority" , take the lead in practice, set up a model for students, and enable school leaders and teachers to put integrity and self-discipline on their hearts, shoulders and actions To promote the formation of a good atmosphere of advocating probity and thrifty, and to provide a good external environment for the cultivation of probity consciousness of college students.

\section{B. We should always use the class of practical ideological} and political theory to give full play to its political guiding role

"Our universities are under the leadership of the Party and are socialist universities with Chinese characteristics” , Xi said. "To run our colleges and universities well, we must adhere to the guidance of Marxism and implement the party's educational policy in an all-round way. We must unremittingly disseminate Marxist scientific theory, do a good job in Marxist theoretical education, and lay a scientific ideological foundation for the growth of students throughout their life”. Ideological and political theory courses shoulder the important responsibility of cultivating qualified constructors and reliable successors for the cause of socialism with Chinese characteristics the political nature of curriculum should always be emphasized in teaching. We should include incorruptibility 
education in the ideological and political course for college students, implement incorruptibility education into the syllabus, teaching materials and classroom, realize the full coverage of incorruptibility education for college students, and give full play to the role of ideological and political course as the main channel Bringing incorruptibility education into the cultivation system of the socialist core values of college students, realizing incorruptibility education in the classroom, and helping college students make it clear that incorruptibility is the eternal moral standard on the road of life, let incorruptibility habit and incorruptibility consciousness accompany the life growth course of college students. To grasp the key of the teachers, the teachers of the ideological and political theory course are directly responsible for spreading the mainstream ideology. Every word and every action is enough to have a direct and significant impact on the cultivation of university students' world outlook and values. We should design and organize classroom teaching arrangements, keep in close contact with current affairs and cognitive characteristics of college students, and emphasize classroom teaching effects. Attaching importance to the combination of theoretical education and case education, the combination of positive guidance and warning education, the combination of history education and current affairs education, and striving to enhance the attractiveness, persuasiveness and appeal of clean education, realizing the ideological and timeeffectiveness of incorruptible education.

\section{Making full use of the position of the party branch and the league branch of college students, so that college students have a sense of incorruptibility}

The Party branch and the League branch of college students are the basis for ensuring the implementation of the party's line, principles, policies, decisions, and arrangements. In strengthening the building of the Party's Work Style and clean government, they should play their role as a strong fighting fortress and give prominence to clean education Promoting the political ability of student cadres and fostering the sense of incorruptibility in the ideological and political work. College Student Party Branch Secretary, League General Branch secretary is generally held by counselors, and the Ministry of Education, counselors must be party members. Therefore, as the Party branch, the General Secretary of the Communist Youth League and the counselor of the ideological and political workers, they should make great efforts in the education of incorruptibility, focusing on cultivating the incorruptibility consciousness of Party members and cadres. Promoting the awareness of probity among college students with the selfdiscipline of Party members and cadres. We should rely on the position of the Student Party branch and the Youth League branch to foster the sense of probity among college students. We will carry out education in ideals and beliefs, education in traditional culture, special education on the building of a clean and honest party, education in strict observance of discipline and rules, and education in core socialist values Promoting the cultivation of college students' good sense of probity. It is necessary to expand new media education and enrich the forms of cultivation, by organizing publicity shop windows, and by using publicity shop windows to hold photo exhibitions and calligraphy and painting exhibitions on combating corruption and advocating clean government. It is necessary to set up online columns, elaborate web pages, and design columns on clean culture We will promote the construction of clean culture in schools in all aspects, open columns on clean culture in school newspapers and enhance the construction of clean culture, and build a learning platform on WeChat to enhance communication and interaction. We should combine the cultivation of incorruptness awareness with social practice, constantly expand activities both inside and outside the campus, build a practical mechanism to "penetrate the hearts of the people" carry out investigations on incorruptness culture, participate in anti-corruption and promotion of incorruptness[6], and visit Revolutionary Memorial sites Visiting the warning education base, visiting the prison, etc. Taking the Party and League Day of university students, the Volunteer Service of university students, and the social practice of "three going to the countryside" in the summer into account to encourage college students to take an active part in various public welfare activities such as Youth Voluntary Service and work-study program, and actively guide students to "go into the community" and carry out propaganda and consultation on clean government culture, so that students can experience clean culture in practice. We can also combine the education of incorruptibility culture with the entrance and graduation ceremonies of the new students to enhance the effect of incorruptibility consciousness cultivation.

\section{Closely surrounding the mainline of socialist core values, arouse the inner consciousness of incorruptibility of college students}

Education must train those who are needed for the development of society. The socialist colleges and universities with Chinese characteristics must take the socialist core values as the mainline and run the socialist core values through the whole process of cultivating the incorruptibility consciousness of college students. Turn the core socialist values into the emotional identity of college students and Behavior Habits, leading college students to develop a correct sense of probity. Take "patriotism, dedication, integrity, friendship" as the basic moral norms of citizens which is the condensation of the basic concept of the socialist core values from the level of personal behavior. It covers every field of social moral life, is the basic moral standard that the citizen must abide by, is also the basic value standard that evaluates citizens moral behavior choice, is also the principle that university students must follow. Its spiritual essence requires all citizens, including university students, to be loyal to their duties, self-restraint, dedication to honest and honest work, and keeping promises, and also contains integrity and self-discipline. Therefore, we should take the socialist core values as the mainline and strengthen the cultivation of the incorruptibility consciousness of college students in strengthening the socialist core values of college students[7]. We should strengthen emotional education and humanistic care, embody and carry forward the socialist core values in teaching, scientific research, management and service, and the construction of campus culture, and give full play to the role of Cultural Education, exemplary influence and teacher's demeanor Imperceptibly. Let the university students accept, trust, like it from their heart, achieving the emotional identity. Guide students learning to actively practice the core 


\section{REFERENCES}

[1] Pan Yewang and Lin Zuojun. A probe into the incorruptibility consciousness education of college students $[\mathrm{J}]$. The rule of law and society, 2018(34): 192-193. (In Chinese)

[2] Chen Baosheng. must adhere to the correct political direction. [N]. Seeking the truth, March 2017 issue 3. (In Chinese)

[3] Deng Xueyuan, Li Guoxing. Strengthen the leadership and discourse power of ideological work in colleges and universities. [N]. Guangming Daily. February 13,2017, page 11 (In Chinese)

[4] Li Wenjiao. A study on college students' incorruptibility consciousness and its cultivation [D]. Mianyang: Southwest University of Science and Technology, 2018. (In Chinese)

[5] Li Bin Xiong. Carry out the education of College Students' honesty and build up the ideological foundation of "don't want to corrupt”. Shaanxi party construction network, October 30, 2018. (In Chinese)

[6] Chen Guoqiu, Nie Guodong, Ju Yinni, Liang Yuan. A study on the incorruptibility education of college students in the new period [J]. The party's history, 2018(9): 62-63. (In Chinese)

[7] Zheng Chaoshuo. A study on the incorruptibility education of college students and its effective mechanism [D]. BEIJING: China University of Mining, 2017. (In Chinese) 